\title{
Norma geral antielisiva encartada no Código Tributário Nacional o confronto entre o princípio da capacidade contributiva e a regra da tipicidade fechada e a pretensa tributação por analogia
}

\author{
Willian Robert Nahra Filho ${ }^{1}$
}

\begin{abstract}
Resumo
Verificar a possibilidade do emprego de norma geral antielisiva no direito pátrio, ou seja, tributação por analogia de fato jurídico extratípico de efeitos econômicos equivalentes a fato jurídico típico, com base na doutrina de abuso de direito e no princípio da capacidade contributiva. Análise em face dos princípios da legalidade estrita e da tipicidade fechada, desdobramentos do princípio da segurança jurídica. Conclui pela impossibilidade de tributação por analogia pela ofensa ao princípio da segurança jurídica, que prima pela certeza e previsibilidade nas relações entre Estado e contribuintes. Pela ofensa ao princípio da legalidade estrita em razão de exigência de lei específica e qualificada para instituição detributos. Pela ofensa ao princípio da tipicidade fechada que impede a tributação de fato jurídico não descrito com todos os seus pormenores em lei. Princípios estes não passíveis sequer de limitação, pois constituem cláusulas pétreas. Impossibilidade de restrição da plena eficácia da regra da tipicidade pelo princípio da capacidade contributiva. Impossibilidade de tributação pelo método integrativo da analogia, pois, existe certa carga, mesmo que relativa, de criatividade inerente ao método e por inexistir lacunas dependentes de preenchimento em matéria pertinente a instituição de tributos, existentes na realidade espaços livres do direito.
\end{abstract}

Palavras-Chave: Norma geral antielisiva; Abuso de direito; Princípio da capacidade contributiva; Princípio da legalidade estrita; Princípio da tipicidade fechada; Regra e princípio; Método analógico; Lacunas.

\section{Introdução}

O contribuinte desde os primórdios dos tempos procura se abster ou recolher o menor tributo possível, como comprovaram estudos de psicologia financeira, citados por Heleno Tôrres, senão vejamos²:

[...] Como bem analisou Günter Schmölders: 'Nadie gusta de pagar impuestos. La historia de la imposición está llena de ejemplos que prueban que el pagode lãs cargas fiscales constituye un penoso deber, a cuyo cumplimiento hay que incitar

Alunao do 5 ano de Direito Matutino Universidade Estadual de Londrina.

SCHMÖLDERS, Günter. Problemas de psicologia financeira. Madrid: Editorial de Derecho Financiero. 1965. p. 112-113 apud TÔRRES, Heleno. Direito tributário e direito privado. São Paulo: Editora Revista dos Tribunais, 2003. p. 173. 
constantemente a los ciudadanos. (...) Por lo común, el impuesto desencadena uma reacción Del individuo contra lo que de coacción aquél comporta y un resentimiento por el sacrificio que su pago representa. El pago Del impuesto aparece ante El psicológico como un 'pago psicologicamente sin motivo', como uma 'ideia psicologicamente motivada solo para una das partes, que em el campo de La conducta fiscal no despierta factores activos positivos, sino resistencia y pasividad'. Lãs investigaciones en el terreno psicológico han demonstrado que el deber fiscal aparece de hecho apartado de la moralidad del individuo'.

O jurista Alfredo Augusto Becker, em sua obra clássica, seguindo o pensamento de Albert Hensel, dizia: "é aspiração naturalíssima e intimamente ligada à vida econômica, a de se procurar resultado econômico com a maior economia, isto é, com a menor despesa", levando-se em conta que os valores recolhidos a título de tributos sempre estarão pendendo para o lado das despesas. Uma alta carga tributária onera a produção, aquele que consegue se desvencilhar dela possui uma grande vantagem sobre seus concorrentes ${ }^{3}$.

Seria ingenuidade esperar que o contribuinte optasse por meio pelo qual recolhe uma maior carga tributária, possuindo diversos outros caminhos legais que chegassem no mesmo resultado com significativa redução em suas despesas, se apresentando mais apto no mercado.

Cânone do Estado Social de Direito, a livre iniciativa é cláusula pétrea em nosso ordenamento, autonomia privada que visa garantir a todos os cidadãos liberdade em administrar seus negócios da maneira que mais lhes aprouver, dentro dos rijos ditames da lei.

O contribuinte pode agir, para redução de suas despesas com recolhimento de tributos, evitando a incidência tributária ou se sujeitando a regime mais favorável sem contrastar frontalmente o ordenamento, mediante legítima economia de tributos; usando de negócios lícitos, que não constituam em simulações, com o objetivo de contornar a norma tributária (elisão); descumprindo a legislação diretamente (evasão); ou utilizando-se de negócios aparentemente válidos, mas constituídos com fraude à lei civil ou simulados e que geram o mesmo efeito ao afastar-se do campo de incidência de tributos ou coincide com hipóteses de incidência menos onerosas (fraude a lei).

Com o intuito de se evitar a prática da elisão fiscal, lícita e calcada no princípio da autonomia privada, muito corrente em tempos de altas cargas tributárias nos quais o

\footnotetext{
3 BECKER, Alfredo Augusto. Teoria geral do direito tributário. 3. ed. São Paulo: Lejus, 1999. p. 136.
} 
Norma geral antielisiva encartada no Código Tributário Nacional: o confronto entre o princípio da capacidade contributiva e a regra da tipicidade fechada e a pretensa tributação por analogia

empresariado cada vez mais recorre ao planejamento tributário para se manter competitivo, o Estado alterou o Código Tributário Nacional ${ }^{4}$ com a edição da Lei Complementar $104^{5}$, de 10 de janeiro de 2001, acrescentando o parágrafo único ao artigo 116, de cunho eminentemente antielisivo, com a seguinte redação:

Art. 116. Salvo disposição de lei em contrário, considera-se ocorrido o fato gerador e existentes os seus efeitos:

I - tratando-se de situação de fato, desde o momento em que se verifiquem as circunstâncias materiais necessárias a que produza os efeitos que normalmente lhe são próprios;

II - tratando-se da situação jurídica, desde o momento em que esteja definitivamente constituída nos termos de direito aplicáveis.

Parágrafo Único: A autoridade administrativa poderá desconsiderar atos ou negócios jurídicos praticados com a finalidade de dissimular a ocorrência do fato gerador constitutivos da obrigação tributária, observados os procedimentos a serem estabelecidos em lei ordinária.

O relator do projeto, Deputado Antonio Cambraia, citado por Cristiano Colombo, manifestou-se a respeito afirmando que, com a inclusão da norma antielisiva, "procura-se evitar, ou minorar os efeitos do chamado planejamento tributário das empresas, das suas tentativas de elisão que produzam o esvaziamento da capacidade contributiva” ${ }^{\prime}$.

Citado na mesma obra, corroborando com o ideário do Deputado Cambraia, o então Deputado Antonio Palocci, aduziu que "em particular, quanto à norma antielisão, é uma necessidade para o Brasil, porque, mais do que nunca, o setor que mais cresce em matéria tributária no país é o do planejamento fiscal." ${ }^{7}$

Sob a cortina da capacidade contributiva, o que deseja o Estado é o aumento da receita proveniente dos tributos, fonte primeira de financiamento do tesouro nacional.

Assim, pendente de regulação, o referido parágrafo único do artigo 116 do Código Tributário Nacional fora prontamente regulamentado pela Medida Provisória $66^{8}$, de 29 de

4 BRASIL. Lei no 5.172, de 25 de outubro de 1966. Dispõe sobre o sistema tributário nacional e institui normas gerais de direito tributário aplicáveis à União, Estados e Municípios. Diário oficial da união, Brasília, Distrito Federal, p. 12.452, pub. 27/10/1966.

5 BRASIL. Lei Complementar no 104, de 10 de janeiro de 2001. Altera dispositivos da Lei 5.172, de 25 de outubro de 1966 - código tributário nacional. Diário oficial da união, Brasília, Distrito Federal, p. 01, pub. $11 / 01 / 2001$.

6 COLOMBO, Cristiano. O planejamento tributário e a norma antielisiva. In: CONGRESSO BRASILEIRO DE DIREITO TRIBUTÁrIO, 15., 2002, São Paulo. [Anais...]. São Paulo: [s.n.], 2002. p. 53.

7 COLOMBO, 2002, loc. Cit.

8 BRASIL. Medida Provisória no 66, de 29 de agosto de 2002. Dispõe sobre a não cumulatividade na cobrança da contribuição para os programas de integração social (PIS) e de formação do patrimônio do servidor 
agosto de 2002, determinando os procedimentos para desconsideração de atos ou negócios jurídicos, para fins tributários.

Quando de sua conversão na Lei $10.637^{9}$, de 30 de dezembro de 2002, os artigos referentes à regulamentação da norma antielisão foram suprimidos, ou seja, tal norma não mais se encontra regulamentada por lei.

Superando as divergências no que tange à auto-aplicabilidade, mesmo sem regulamentação, do dispositivo antielisivo e a interpretação do termo "dissimular" incluso no diploma legal, surge a necessidade de análise da norma geral antielisão em face dos princípios da legalidade estrita, garantida pelo artigo 150, inciso I, da Constituição Federal ${ }^{10}$; da tipicidade fechada, que é corolário da legalidade estrita, também albergado pelo artigo 150, I, da Constituição Federal; e por fim, verificar a possibilidade de instauração da tributação por analogia no direito tributário pátrio, imbuído dos princípios da certeza e da segurança das relações jurídicas.

Tendo como supedâneo a garantia constitucional da tutela do direito ao exercício da autonomia privada, à propriedade e à liberdade contratual, o presente trabalho procura fundamentar a possibilidade do contribuinte se utilizar ou não da elisão fiscal, verificando a possibilidade de sobrevivência, através de uma interpretação sistemática, da pretensa norma antielisiva em nosso ordenamento jurídico.

público (PASEP), nos casos que especifica; sobre os procedimentos para desconsideração de atos ou negócios jurídicos, para fins tributários; sobre o pagamento e o parcelamento de débitos tributários federais, a compensação de créditos fiscais, a declaração de inaptidão de inscrição de pessoas jurídicas, a legislação aduaneira, e da outras providências. Diário oficial da união, Brasília, Distrito Federal, pub. 30/08/2002, p. 01.

9 BRASIL. Lei no 10.637, de 30 de dezembro de 2002. Dispõe sobre a não-cumulatividade na cobrança da contribuição para os programas de integração social (PIS) e de formação do patrimônio do servidor público (PASEP), nos casos que especifica; sobre o pagamento e o parcelamento de débitos tributários federais, a compensação de créditos fiscais, a declaração de inaptidão de inscrição de pessoas jurídicas, a legislação aduaneira, e da outras providências. Diário oficial da união - seção extra, Brasília, Distrito Federal, pub. 31/12/2002, p. 01.

10 BRASIL. Constituição (1988). Constituição da república federativa do Brasil. Brasília, Distrito Federal, 1988. 
Norma geral antielisiva encartada no Código Tributário Nacional: o confronto entre o princípio da capacidade contributiva e a regra da tipicidade fechada e a pretensa tributação por analogia

\section{Elisão e evasão fiscal}

\subsection{Pacto semântico - emprego dos termos elisão e evasão fiscal}

A concepção do que se poderia entender por elisão fiscal e por evasão fiscal não se encontra pacífica na doutrina, as variantes são inúmeras, utiliza-se termos contrapostos, verbi gratia, como elusão, evasão e elisão fiscal; evasão lícita e evasão ilícita, entre inúmeros outros. Isto acontece, pois, não há denominação no campo jurídico para tais condutas e nem ao menos denotação científica para tal.

Como os termos são adotados de forma pessoal e subjetiva por cada autor, inexistindo definição jurídica própria e, levando-se em consideração, ainda, que os argumentos levados a cabo são coerentes, entendemos que a utilização de um termo a outro é mera questão de pacto semântico, importando mais o espírito que o nomen iures.

Adota-se, como pacto semântico, as expressões utilizadas pelo jurista Sampaio Dória em sua obra "Elisão e evasão fiscal" "11 , quais sejam, elisão fiscal e evasão fiscal, termos estes, apesar de não serem unanimidade, são os mais adotados pela doutrina.

Para Sampaio Dória, a elisão fiscal seria definida como todo ato ou omissão que tende a evitar, reduzir ou retardar o pagamento de um tributo. Já a evasão fiscal, sempre ilícita, seria a ação consciente e voluntária do devedor tendente a, por meios ilícitos, eliminar, reduzir ou retardar o pagamento do tributo efetivamente devido ${ }^{12}$.

Contrapondo-se aos outros termos empregados, em especial à dicotomia evasão lícita e evasão ilícita, outrossim, com o intuito de justificar a utilização do termo elisão, aduz o doutrinador a contradição implícita do termo "evasão lícita", já que a expressão "evasão", em si mesma considerada, já conotaria a prática de um ato ilícito, uma certa irregularidade, uma dissimilação para se evitar a tributação ${ }^{13}$ :

O exemplo clássico é a chamada evasão de presos. Se dissermos evasão ilícita, estaremos pleonasticamente qualificando um ato que por si só já é ilícito. E se dissermos evasão lícita estaremos criando uma certa contradição nos termos, pois o núcleo desta alocução, o termo 'evasão', por si só, já implica essa idéia de ilicitude.

11 SAMPAIO DÓRIA, Antonio Roberto. Elisão e evasão fiscal. São Paulo: Lael, 1971. p. 21.

SAMPAIO DÓRIA, 1971, op. cit., p. 451.

SAMPAIO DÓRIA, 1971, loc. cit. 
Propõe-se o emprego no presente trabalho da expressão evasão para significar a fraude fiscal, lato sensu, e o termo elisão para exprimir a evasão lícita ou legítima, chave mestra do planejamento tributário.

\section{Norma geral antielisiva encartada no parágrafo único do artigo 116 do Código} Tributário Nacional

\subsection{Breves considerações}

Com o acréscimo da norma geral antielisiva insulada no parágrafo único do artigo 116 do Código Tributário Nacional, outorgou-se a autoridade administrativa, mediante a observação de procedimentos a serem estabelecidos em lei, o direito de desconsiderar atos ou negócios jurídicos praticados pelos contribuintes com o intuito de dissimular a ocorrência do fato gerador do tributo.

A norma geral antielisiva pátria pretende tributar por analogia fato jurídico extratípico, que alcance resultado econômico equivalente ao de fato jurídico típico, sem contudo produzir as mesmas conseqüências tributárias.

A norma antielisiva é geral, não porque abrange todos os administrados, mas sim por pretender regular todas as situações nas quais há virtual imperfeição na descrição do fato jurídico, tributando por analogia outras condutas que não somente aquelas qualificadas em norma específica, com aduz Heleno Tôrres ${ }^{14}$ :

\footnotetext{
por serem espécies de normas gerais e abstratas cuja materialidade da hipótese normativa encontra-se ordenada para regrar os demais casos não qualificados na hipótese de incidência de normas específicas, atribuindo pressupostos aos casos que possam ser alcançados, para a aplicação da sanção prevista no conseqüente: a desconsideração e requalificação dos negócios operados elusivamente.
}

O baluarte fundante da norma geral antielisiva nacional é a teoria do "abuso de direito", na qual a Fazenda Pública ante uma interpretação dos fins econômicos pretendidos pelo contribuinte (conduta tomada com intenção puramente fiscal, sem cunho empresarial), para atender ao princípio da capacidade contributiva, pretende tributar fato jurídico extratípico por analogia.

14 TÔRRES, 2003, op. cit., p. 237. 


\subsection{Pressupostos de aplicação da norma geral antielisiva pátria}

Inovador neste aspecto, o jurista Alberto Xavier, através de estudo comparado entre as inúmeras cláusulas gerais antielisivas de diversos países, concluiu que na sua essência, de forma sistemática, seriam três os pressupostos de aplicação de normas antielisivas e conseqüente incidência por analogia do tributo, quais sejam:

a) a livre opção pela prática de ato ou negócio jurídico ou conjunto de atos ou negócios jurídicos não tipificados pela referida norma tributária (ou tipificados por outra norma tributária de regime menos oneroso);

b) a obtenção através deste ato ou conjunto de atos de um resultado econômico equivalente ao do ato ou negócio tributado ou mais onerosamente tributado;

c) o fim elisivo, consistente em subtrair o ato praticado ou o conjunto de atos praticados no âmbito de aplicação da norma tributária. ${ }^{15}$

Tais pressupostos são totalmente aplicáveis ao direito pátrio, que deverão ser verificados cumulativamente para possível aplicação por analogia ao fato jurídico extratípico praticado, de resultados econômicos equivalentes, norma tributária de fato jurídico típico.

Deflui-se da conjugação dos três pressupostos esposados a observância dos resultados, dos fins e dos meios utilizados pelo contribuinte para a prática da conduta elisiva.

Usando como vetor os pressupostos elencados, conclui-se que fogem ao âmbito da incidência da norma geral antielisiva as hipóteses: em que não houve a livre opção por um modelo negocial alternativo, em que a livre opção não atingiu resultado econômico equivalente; e por fim naquela em que a livre opção atingiu resultado econômico equivalente, mas não teve por fim exclusivo ou preponderante a não-incidência, a redução de tributo ou a obtenção de benefício fiscal.

Tome-se como exemplo um caso hipotético, em que o indivíduo " $A$ " pretende realizar um contrato de mútuo com o indivíduo " $\mathrm{B}$ ", sendo o indivíduo " $\mathrm{A}$ " credor e o indivíduo " $\mathrm{B}$ " devedor; tem-se que o contrato de mútuo é tributado pelo Imposto de Renda sob alíquota de $15 \%$. Contudo, a venda de bem imóvel, neste caso hipotético, é isento de tributação. Destarte, o indivíduo "B" elabora um contrato de compra e venda de um bem imóvel com cláusula de retrovenda, no qual depois de determinado período poderá realizar

15 XAVIER, 2002, op. cit., p. 88. 
a recompra de seu bem sob o domínio do indivíduo " $\mathrm{A}$ ", acrescidos dos juros referentes ao empréstimo.

O ato praticado no caso apresentado seria, teoricamente, passível de desconsideração pela Administração Pública, já que a transação não possuía caráter empresarial, havendo apenas intenção de não recolhimento de tributos pelo fisco; sublinhese que no caso hipotético não houve simulação ou fraude à lei, toda a transação ocorreu de forma totalmente lícita.

A liberdade de escolha do meio pelo qual realizou se o negócio é imanente ao Estado de Direito que prima pela livre iniciativa, alcançando resultado econômico equivalente ao de um contrato de mútuo, de forma lícita, evitando assim a aplicação da norma tributária de forma plenamente lícita.

Se o contribuinte não agiu com dolo, fraude ou má-fé e, entre as duas leis, escolheu aquela que Ihe fora mais favorável, não há subsídios para a Fazenda Pública contestar a operação.

Caso a escolha do diploma legal realizada pelo contribuinte não agradou ao Estado, este deve revogar o diploma pelo Poder Legislativo que lhe deu fundamento, pelos meios legislativos constitucionais expressos nos artigos 59 a 69 da Constituição Federal, nunca através de uma inconstitucional tributação por analogia ensejada por uma não menos inconstitucional norma geral antielisiva.

O ponto nevrálgico, contudo, jaz no fato de que as normas gerais antielisão permitem realmente à Fazenda Pública desconsiderar o fato extratípico (praticado inteiramente de forma lícita) que produza efeitos econômicos equivalentes a fato típico, praticado com o intuito de subtrair a conduta do âmbito de aplicação da norma tributária, que prevê o fato típico, para aplicação por analogia ao fato extratípico norma de incidência tributária do fato típico, numa total afronta ao ordenamento pátrio.

\subsection{Fundamentos da norma geral antielisiva pátria}

A corrente que melhor fundamenta a aplicação da norma geral antielisiva no ordenamento pátrio é a teoria do "abuso de direito", de raízes francesas, que busca no princípio da capacidade contributiva o fundamento para, realizando assim o princípio da igualdade, desconsiderar os atos e negócios jurídicos indiretos, que eliminam, reduzem ou 
Norma geral antielisiva encartada no Código Tributário Nacional: o confronto entre o princípio da capacidade contributiva e a regra da tipicidade fechada e a pretensa tributação por analogia

retardam o pagamento dos tributos, ainda que lícitos, se a intenção for puramente fiscal. É o que explicita Lais Vieira Cardoso ${ }^{16}$ :

O parágrafo único do artigo 116 não prevê utilização do critério econômico de tributação, o que demandaria ao Fisco considerar o resultado econômico almejado e obtido pelo contribuinte e advindo do ato simulado e, sim, o critério jurídico de abuso de direito ou de formas, preconizando a própria forma simulada deste ato negocial e sua finalidade única de burlar a regra de incidência tributária para obter os resultados mediatos de evitar, reduzir ou retardar a tributação sem se amoldar a nenhuma finalidade empresarial ou contratual.

O abuso de direito de forma geral poderia se caracterizar pelo exercício egoístico, anormal do direito, sem motivos legítimos, com excessos intencionais ou voluntários, dolosos ou culposos, nocivos a outrem, contrário ao critério econômico e social do direito em geral.

O raciocínio jurídico da teoria do abuso de direito aplicado ao direito civil, privado, é diferente daquele aplicado ao direito tributário, público. As situações fáticas produzidas não possuem similitude alguma, com, por exemplo, atos meramente emulativos, como a construção de uma cerca na passagem utilizada pelo vizinho mal quisto.

Vários autores sustentam a possibilidade da aplicação da analogia mais gravosa, in malem partem, com o escopo de se evitar a elisão fiscal, contudo, salvo particularidades, embasam a estrutura de suas teses no estudo do jurista alemão Klaus Tipke, que em 1978 publicou obra aplicando a teoria do abuso de direito com os fins apresentados. Tipke sustenta sua teoria no fato de os princípios da isonomia e da capacidade contributiva serem hostis a que sejam tratados de modo discriminatório atos ou negócios jurídicos de efeitos econômicos equivalentes, e que justificariam o recurso à integração por analogia na seara do direito tributário. ${ }^{17}$

O direito de os contribuintes terem liberdade para organizar os seus negócios, das formas mais vantajosas e adequadas possíveis, existe, contanto que não sejam efetuados com o único sentido de economia de tributos, abusando de seus direitos.

16 CARDOSO, Lais Vieira, As doutrinas de prevalência da substância sobre a forma diante do parágrafo único do artigo 116 do código tributário nacional. In: CONGRESSO BRASILEIRO DE DIREITO TRIBUTÁRIO, 15, 2002, São Paulo. [Anais...]. São Paulo: [s.n.], 2002. p. 272.

17 XAVIER, 2002, op. cit., p. 102. 
Para Klaus Tipke a defesa intransigente da segurança jurídica corresponde a um pensamento positivista, ligado ao Estado de Direito formal, mas inadequado face ao moderno Estado de Direito material, contrapondo a idéia de Estado Democrático com a de Estado Social como justificador de uma solidariedade contributiva. Por isso, caso se comprove que o contribuinte, pelo uso de forma inusuais, modelou juridicamente um fato econômico revelador de capacidade contributiva, de modo a evitar a tributação, o princípio da segurança jurídica deve ceder perante o princípio da capacidade contributiva, cabendo até a legitimação para imposição do tributo por analogia.

A utilização pelo contribuinte de formas inusuais para a realização de seus negócios visando evitar a tributação, segundo Tipke, escamoteia sua capacidade contributiva, já que não há o esgotamento de seu poder contributivo, infringindo o princípio da igualdade e incorrendo em verdadeiro abuso de direito.

O princípio da segurança jurídica, em sua teoria, sede em razão do princípio da capacidade contributiva, pois, o fim colimado pelo contribuinte causa um dano, uma lesão à Fazenda Pública e indiretamente a todo cidadão, legitimando então o Estado a proceder a tributação por analogia.

Adotando o ideário de Klaus Tipke no Brasil, Marco Aurélio Greco estrutura seu pensamento nos mesmos moldes, adotando a idéia de limitação ao poder de autoorganização, a aplicação do princípio da capacidade contributiva como garantidor da igualdade e mitigador do princípio da tipicidade, contudo, inovador neste aspecto, defende uma eficácia positiva do princípio da capacidade contributiva.

Tal premissa funda-se na idéia de que a capacidade contributiva deve ser alcançada onde quer que esteja, possuindo uma eficácia positiva, alcançando a capacidade de contribuir dos cidadãos de forma plena, ampla, mesmo que para tal recorra ao método da integração por analogia, para além das fronteiras da tipicidade. Como discorreu Alberto Xavier citando Marco Aurélio Greco ${ }^{18}$ :

Onde, porém, a tese de MARCO AURÉLIO GRECO se revela audaciosamente original (e que é a premissa maior do seu raciocínio) é na afirmação de uma 'eficácia positiva da capacidade contributiva', significando que o referido princípio não é apenas um limite negativo à tributação, mas um comando pelo qual 'a lei tributária tem de alcançá-la até onde ela for detectada; ou seja, o princípio funciona como

18 XAVIER, 2002, op. cit., p. 104-105. 
um vetor do alcance da legislação. Em outras palavras: a lei tributária alcança o que obviamente prevê, 'mas não alcança apenas isto, alcançando, também, aquilo que resulta da sua conjugação positiva com o princípio da capacidade contributiva.

A doutrina propagada por Klaus Tipke e temperada pela eficácia positiva da capacidade contributiva incluída por Marco Aurélio Greco visa uma mitigação do princípio da tipicidade quando o contribuinte incorrer em possível abuso de direito, tornando princípio vetor mestre da tributação não o princípio da tipicidade fechada, e sim o princípio da capacidade contributiva.

\section{0 conflito entre a regra da tipicidade e o princípio da capacidade contributiva}

Antes de tudo, forçoso asseverar que a pretensa qualidade ou eficácia positiva do princípio da capacidade contributiva, limitativo imanente do direito de autoorganização dos cidadãos não encontra respaldo constitucional, já que os direitos e garantias fundamentais não podem sofrer quaisquer limitações.

Apesar disso, tem-se de forma clara a divergência de funções entre a princípio da tipicidade (tido como regra) e o princípio da capacidade contributiva (albergado como princípio somente), tornando impossível a prevalência da teoria da eficácia positiva do princípio da capacidade contributiva como limitadora dos efeitos da tipicidade cerrada.

Os princípios quando insertos no sistema jurídico podem se apresentar na forma de princípios propriamente ditos ou constituírem-se em regras, não significa dizer que o princípio se transformou em regra, apenas se mostra como tal para o sistema, coexistindo o princípio e a regra que dele se originou.

Princípios e regras são espécies do gênero norma, como afirma José Joaquim Gomes Canotilho, ao sugerir o abandono da já ultrapassada distinção entre normas e princípios, substituindo pelas premissas: "as regras e princípios são duas espécies de normas; a distinção entre regras e princípios é uma distinção entre duas espécies de normas". 19

A distinção entre princípio e regra é tarefa particularmente complexa, pelo grande número de critérios, pontos de referência, sugeridos pela doutrina. Abordaremos sob a perspectiva de sua aplicabilidade.

19 CANOTILHO, 1999, op. cit., p. 1144. 
Ao se buscar a distinção entre princípio e regra, deve se esclarecer duas questões fundamentais: saber qual a função dos princípios, ou seja, se são apenas normas de conduta ou retórico-argumentativas; saber se entre princípios e regras há apenas uma diferença de grau na abordagem dos temas, possuindo, verbi gratia, o princípio um grau de abstração maior que a regra, ou se as diferenças são em função da qualidade, distinção somente qualitativa.

No que se refere ao primeiro problema, deve se distinguir entre princípios hermenêuticos e princípios jurídicos, nos termos de José Joaquim Gomes Canotilho. Os princípios hermenêuticos possuem uma função argumentativa, explicitam a ratio legis de uma disposição, que não esta expressa por disposição alguma, contudo, não é o bastante para descortinar o problema. $^{20}$

A principal distinção entre regra e princípio é de ordem qualitativa. Os princípios são normas de otimização do sistema, compatíveis com diferentes graus de aplicação, de concretização, conforme os casos se apresentem no mundo fenomênico, podendo-se aplicálas em maior ou menor grau; as regras são norma cogentes, preenchidos seus pressupostos exigem sua aplicação, contém um imperativo (modais deônticos: impõem, permitem ou proíbem) que são ou não cumpridos.

A relação entre os princípios nunca é conflitante, pois permitem um balanceamento de valores e interesses, podem ser aplicados em menor ou maior grau; as regras são excludentes, se duas regras conflitam uma deve ser expurgada do sistema, uma regra deve ser cumprida na exata medida de seu mandamento, nem mais nem menos. Como reforça José Joaquim Gomes Canotilho ${ }^{21}$ :

[...] os princípios coexistem, as regras antinômicas excluem-se.

[...] em caso de 'conflito entre normas e princípios', estes podem ser objecto de ponderação e de harmonização, pois eles contêm apenas "exigências» ou "sstandards» quem, em "(primeira linha» ('prima facie'), devem ser realizados; as regras contêm «fixações normativas» 'definitivas', sendo insustentável a 'validade' simultânea de regras contraditórias.

Quando em conflito, as regras suscitam problemas de validade, se são aplicáveis integralmente ou não, excluindo necessariamente uma delas; os princípios suscitam

20 CANOTILHO, 1999, loc. cit.

21 CANOTILHO, 1999, op. cit., p. 1145. 
problemas de validade, como as regras, e, particularmente, de peso, onde se pondera um maior alcance ou importância de um princípio sobre outro, harmonizando-os sem a necessária exclusão de algum.

É justamente esta dicotomia que se apresenta no ordenamento pátrio, na qual falaciosamente concluem os defensores da norma geral antielisão pela prevalência do princípio da capacidade contributiva sobre o princípio da tipicidade fechada, que na realidade é um conflito entre o princípio da capacidade contributiva e a regra da tipicidade fechada.

O princípio da tipicidade fechada se mostra no ordenamento como regra, já que prescreve um imperativo, como expresso está no artigo 150, inciso I do Código Tributário Nacional, "é vedado exigir ou aumentar tributos sem lei que o estabeleça", ou no artigo 97 e incisos do mesmo diploma legal: somente a lei pode estabelecer: a definição de fato gerador da obrigação principal, a fixação de alíquota e base de cálculo. As regra são cogentes, caso possuam validade devem ser aplicadas integralmente ou excluídas do sistema.

O princípio da capacidade contributiva, ao revés, não se mostra como regra, já que, por força da própria natureza de princípio o ordenamento não lhe impôs um imperativo, e sim um "reserva do possível", como afirmou Alberto Xavier ${ }^{22}$.

Como está expresso no artigo $145 \S 1$ da Constituição Federal, determinando que "sempre que possível, os impostos terão caráter pessoal e serão graduados segundo a capacidade econômica do contribuinte".

Diante desta diferença de natureza e de exigibilidade, impossível é o sobrepujamento da regra da tipicidade fechada pelo princípio da capacidade contributiva, mesmo lançando-se mão da teoria da eficácia positiva da capacidade contributiva sustentada por Marco Aurélio Greco. Para a regra é tudo ou nada, ou existe ou deve ser excluída, a tipicidade fechada é uma regra, denota um imperativo; os princípios são ajustáveis, inclui-se o fator peso para sua harmonização, o princípio a capacidade contributiva é propriamente um princípio, norteador de uma conduta, gravado pelo "sempre que possível" da Constituição Federal.

A regra, categórica e definitiva, nunca pode ser excluída do sistema ao colidir com um princípio, ambos devem coexistir harmonicamente, o princípio cedendo força para que a

22 XAVIER, 2002, op. cit., p. 126. 
regra extravase e exija o cumprimento do seu operador deôntico, verdadeiro imperativo jurídico.

\section{Da aplicação da analogia em direito tributário em face dos princípios da}

\section{legalidade e da tipicidade da tributação}

\subsection{Analogia - método integrativo}

A analogia em direito é um método de integração das normas jurídicas pelo qual, diante de dois fatos idênticos, há de ser aplicada a mesma regra de direito, por força do inafastável princípio da igualdade jurídica. Através da analogia, o intérprete aplica uma determinada norma, relativa a um fato, a outro não regulado, mas semelhante ao anterior, vigorando o brocardo jurídico ubi eadem ratio, ibi eadem juris dispositivo (onde há a mesma razão deve haver a mesma disposição do direito).

Método este de integração, pois, visa o preenchimento de uma lacuna, mesmo que somente relativamente inovador, possui carga criativa, não mero método interpretativo.

Para Paulo de Barros Carvalho, a tarefa de "interpretar" precede a de "integrar", pois, antes de tudo, a primeira atividade consiste em evitar a contradição entre as normas, através da análise do alcance das palavras contidas no texto, solucionar o concurso de norma e regulações e delimitar, entre si, as órbitas de regulação, dando unicidade como requer todo texto legislativo. ${ }^{23}$

A missão da interpretação da lei é harmonizar o sistema legal, resolver questões de conflitos entre normas e entre regulações das mesmas, indicando qual a solução a ser aplicada, imbuído dos princípios que norteiam a direito. A integração se consubstancia num empenho intelectual diverso da interpretação, no caso utilizando-se o método analógico, é preencher uma real lacuna existente no diploma normativo, harmonizando o sistema como a interpretação, mas munido de uma carga criativa maior, já que aproxima casos semelhantes, análogos, nunca idênticos.

Para Ricardo Lobo Torres a grande diferença entre interpretação e integração, portanto, está em que, na primeira, o intérprete visa a estabelecer as premissas para o processo de aplicação através do recurso à argumentação retórica, aos dados históricos e às

23 CARVALHO, 2004, op. cit., p. 96. 
Norma geral antielisiva encartada no Código Tributário Nacional: o confronto entre o princípio da capacidade contributiva e a regra da tipicidade fechada e a pretensa tributação por analogia

valorizações éticas e políticas - buscando-se a mens legislatoris -, tudo dentro do sentido possível do texto, buscando o significado mais apropriado às palavras para uma harmonização perante o sistema; já na integração o aplicador se vale dos argumentos de ordem lógica, como a analogia e o argumento a contrario, operando fora da possibilidade expressiva do texto da norma, inovando, mesmo que relativamente, no direito. ${ }^{24}$

Neste sentido, o próprio Código Tributário Nacional diferencia os dois processos, ao definir, em seu artigo 107, a interpretação e, no artigo 108, a integração.

Alberto Xavier tem para si que a analogia é uma forma de pensamento, raciocínio ou argumento segundo o qual se deve dar idêntica disciplina a uma situação da vida não prevista pelo ordenamento jurídico, contudo, como ponto nodal unânime em relação a todos os outros autores, deve apresentar em relação a outra situação da vida disciplinada pelo mesmo ordenamento um tal grau de características comuns que justifica a igualdade de tratamento ${ }^{25}$.

\begin{abstract}
A analogia é uma segunda etapa de 'captação do Direito', que pressupõe a interpretação, mas não se confunde com ela. Pressupõe a interpretação pois, sem que previamente tenham sido interpretadas as normas potencialmente aplicáveis, não pode formular-se um juízo declarativo de sua inaplicabilidade ao caso concreto e da conseqüente existência de um caso omisso. Mas não se confunde com a interpretação, pois mesmo quanto esta é extensiva, o caso concreto encontra-se já previsto, se não na letra, no espírito da lei, enquanto na integração analógica o caso concreto não se subsume à norma, encontrando-se para além dos seus limites de aplicação. E daí que a integração analógica não revista caráter interpretativo, mas criativo (grifos nossos).
\end{abstract}

Conclui-se que a analogia é método de integração do direito, visto que procura preencher lacunas a fim de harmonizar o sistema, uno que é, numa verdadeira inovação do direito (carga criativa); diferenciando-se da interpretação, que visa esmiuçar o significado das palavras com o mesmo escopo de harmonização do sistema.

\footnotetext{
24 TORRES, Ricardo Lobo. Normas de interpretação e integração do direito tributário, Rio de Janeiro : Forense, 1991, p. 23 apud PALHARES, Cinthia Rodrigues Menescal. A integração no Direito Tributário: considerações acerca do emprego da analogia. Jus Navigandi, Teresina, a. 6, n. 58, ago. 2002. Disponível em: <http://www1.jus.com.br/doutrina/texto.asp?id=3103>. Acesso em: 11 jun. 200

25 XAVIER, 2002, op. cit., p. 143.
} 


\subsection{Pressupostos de validade para aplicação da analogia em direito}

Seriam três os pressupostos de validade para aplicação do método integrativo da analogia em direito: a existência de lacuna, a similitude dos casos ou identidade de razão de decidir e a inexistência de vontade contrária do ordenamento jurídico.

A existência de lacuna caracteriza-se pela ausência de previsão legal expressa e específica de um fato da vida, verdadeira "omissão", na qual o legislador cometeu um deslize, algum erro na elaboração da lei.

Há similitude dos casos quando os dois fatos da vida, um deles regulado expressamente pelo direito e outro omisso, residindo numa lacuna, possuem a mesma identidade de razão jurídica, ou seja, todos os elementos que envolvem os fatos são semelhantes, análogos, afins. Atente-se que a semelhança requerida não jaz somente no elemento fático, invadindo, outrossim, o mundo dos valores.

O último dos pressuposto de aplicação da analogia é a inexistência de vontade contrária do legislador à integração. O ponto nodal é saber se o legislador omitiu determinado mandamento por erro ou não procedeu a regulação do dispositivo de forma intencional, se a norma necessita de integração para a devida e necessária aplicação do direito ou se a omissão alberga o "direito geral de liberdade".

Deve se verificar se o ordenamento permite a aplicação da integração por analogia à "lacuna", se a matéria tratada admite tal integração, já que a analogia utiliza-se de casos apenas semelhantes, não iguais.

Este é o ponto nodal, se a omissão deve ou não ser regulada ou preenchida, e essa regulação ou preenchimento coaduna com os princípios informadores tão característicos do direito tributário, como os princípios da legalidade e da tipicidade.

\subsection{O emprego da analogia no direito tributário em face dos princípios da legalidade e da tipicidade da tributação - lacuna e espaço livre do direito}

Em direito tributário, principalmente no que se refere às normas instituidoras de tributos, vige o princípio da tipicidade fechada, não existem lacunas a serem preenchidas pelo método analógico, visto que os conceitos de taxatividade e numerus clausus são incompatíveis com sua existência. 
Norma geral antielisiva encartada no Código Tributário Nacional: o confronto entre o princípio da capacidade contributiva e a regra da tipicidade fechada e a pretensa tributação por analogia

O princípio da tipicidade fechada, desdobramento do princípio da legalidade estrita (norma qualificada) implantado constitucionalmente veda a aplicação da analogia em direito tributário, visto que a analogia, como método integrativo, possui uma carga de inovação no direito maior que a simples interpretação, possuindo verdadeira carga criativa, mesmo que de modo vinculado, complementar ou derivado, possível somente por meio do Poder Legislativo.

Mesmo a criatividade não possuindo a mesma natureza daquela exercida pelo Poder Legislativo, não se pode negar que há carga criativa, como afirma Alberto Xavier ${ }^{26}$ :

É certo que esta criatividade não é idêntica à criatividade da lei, que é originária, mas derivada, vinculada, complementar ou secundária: mas precisamente por ser (embora limitadamente) um fenômeno criativo, foi ele, de há muito tempo, objeto de proibição, nos terrenos abrangidos pelo princípio da legalidade e da tipicidade (como o penal e o tributário), por o subjetivismo na aplicação do direito perturbar a segurança jurídica e desvirtuar potencialmente a estrita separação de poderes.

A carga criativa é incompatível com as funções estritas do aplicador do direito, violando o princípio da separação de poderes, sendo, mais, incompatível com os postulados da segurança jurídica, na certeza e previsibilidade que deve imperar nas relações entre o Fisco e seus contribuintes.

Bem andou o legislador pátrio ao proibir explicitamente o uso da analogia no direito tributário quando seu emprego resultar em exigência de tributo não previsto em lei, como esta insulado no artigo 108, $\S 1$ 음 do Código Tributário Nacional, fato este que se alinha ao expresso nos artigos 150, inciso I e 146, inciso III, alínea a da Constituição Federal.

O direito privado é pontuado por lacunas que em sua maioria exigem preenchimento por sua própria natureza, pois albergam situações da vida privada impossíveis de catalogação completa, contudo, quando o tema trata-se de direito público, em especial o penal e o tributário, por possuírem princípios próprios e característicos, impingido os de uma "feição fragmentária", em que as lacunas são na realidade "espaços livre do direito", não há vontade do legislador para o seu preenchimento. São justamente espaços livres para ação dos cidadão, verdadeiros "espaços livres" do direito, nos quais vigora o princípio geral de liberdade.

26 XAVIER, 2002, op. cit., p. 142. 
O próprio princípio da seleção que norteia os legisladores a aleger determinados eventos da vida para incidência de tributos faz com que surjam espaços livres, portanto, não selecionados e não queridos pelo legislador como hipóteses de incidência, tornando cristalina a idéia de que tais apontamentos são característicos do Poder Legislativo, e não do aplicador do direito.

Essa característica fragmentária do direito penal e tributário decorre claramente do princípio da tipicidade; fechados em numerus clausus, os tipos, tanto penais como tributários, não devem abranger todas as ações humanas, possuindo espaços de livre ação dos cidadãos, não configurando esses espaços propriamente em "lacunas", e sim "espaços livres do direito".

Tais espaços vazios não são lacunas, pois não há a aspiração pelo legislador de completá-las, como assevera Karl Larenz ${ }^{27}$ :

\footnotetext{
Só se pode falar de 'lacunas' de uma lei quando esta aspira a uma regulação completa em certa medida, para um determinado sector. [...]

Mas mesmo quando se parte da idéia de uma ordem jurídica totalmente codificada, esta só contém 'lacunas' enquanto a questão de que se trata é em absoluto suscetível e está necessitada de regulação jurídica.
}

O doutrinador citado diferencia as lacunas em normativas e de regulação. As lacunas normativas não são propriamente lacunas, mas espaços livres de direito, em que o legislador deixou de albergar em um diploma legal alguma situação da vida, de forma intencional; as lacunas de regulação são as lacunas propriamente ditas, que necessitam de regulação para a aplicação do direito preso pela imperfeição legislativa.

No âmbito destes conceitos, Chäin Perelman adverte no sentido de que as noções de lacuna e vazio nada mais são que metáforas, que no direito podem suscitar algumas dificuldades e, sobretudo, controvérsias. Todavia seu princípio é simples: o juiz pode preencher as lacunas, mas não o vazio, que vem a exigir ação do legislador. ${ }^{28}$

Onde o legislador não pretendeu que a norma tenha essa função reguladora, o caso de possível omissão não é uma verdadeira lacuna, mas lacuna meramente aparente, em

\footnotetext{
27 LARENZ, Karl. Medotologia da ciência do direito. Trad. José Lamego, 2ạ ed., Lisboa: Fundação Calouste Gulbekian, p.448 apud PALHARES, 2002, op. cit.

28 PERELMAN, Chäin (Ed.), Le problemé des lacunas en droit: Essai de synthése, Le problemé des lacunes em droit, Bruxelles: E. Bruylant, 1968, p. 539 apud PALHARES, 2002, op. cit.
} 
verdade espaço livre do direito. O conceito de lacuna pressupõe uma intenção regulatória, de tal modo que se esta intenção não existe, de lacuna não pode se falar.

A lacuna corresponde a uma 'incompletude insatisfatória' 'contrária ao plano' do legislador, decorrente de erro ou imperfeição no desempenho de suas funções, pressupondo, por isso, a constatação de uma vontade de regulação. Também linha mestra do ideário de Heleno Tôrres ${ }^{29}$ :

\begin{abstract}
Definitivamente, não me parece cabível falar na existência de 'lacunas' no âmbito de incidência dos tipos tributários impositivos. Ou as normas tributárias alcançam o fato, por seu conceito encontrar-se no campo semântico do conceito da norma (subsunção) - plano de incidência -, ou não o alcançam, quando suas propriedades não permitam adequação ao campo de abrangência semântica da norma tributária, ficando no domínio da não-incidência. A opção pela seleção dos fatos que podem ser tributados é decisão exclusivamente legislativa, da mesma sorte que é decisão tipicamente legislativa deixar de fora os fatos aos quais não pretenda atribuir a incidência de normas tributárias, numa espécie de declaração do não-tributável, por omissão na tipificação, o que alguns denominam de 'vazios legais desejados'.
\end{abstract}

Assim, impossível a aplicação da analogia em direito tributário insistir em uma permissão para tais métodos equivaleria num total desrespeito aos princípios republicanos da independência dos poderes, transferindo o poder de legislar à Administração Pública, além de infringir o basilar princípio da segurança jurídica, dos quais são corolários os princípios da legalidade e da tipicidade.

\title{
6 Conclusão
}

O emprego de norma antielisiva no direito pátrio é um abuso do poder de tributar, verdadeira violência contra a Constituição Federal e contra a sociedade que a representa.

Os princípios da tipicidade fechada e da legalidade estrita impedem qualquer tributação que não seja aquela prevista em lei, com todos os seus pormenores descritos expressamente, de forma clara e anterior à sua aplicação.

Os princípios da legalidade estrita e da tipicidade fechada são verdadeiras cláusulas pétreas, atentar se contra estes princípios é violar o cerne da constituição, aquilo que a sustenta, qual tronco à árvore, ante às intempéries políticas, sempre agressoras do ordenamento jurídico.

29 TORRES, 2003, op. cit., p. 229-230. 
Corolários do princípio da segurança jurídica, afrontá-los é retornar aos tempos negros de chumbo, tolhendo direitos e garantias fundamentais, criando um ambiente de incertezas e abusos imprevisíveis. Tributar sem lei anterior devidamente "legislada" é atentar contra o contrato social que une os indivíduos como nação.

Arvorar se no princípio da capacidade contributiva, acrescido da nefasta qualidade de "eficácia positiva", para promover a tributação por analogia é uma total afronta ao ordenamento jurídico, é investir de qualidades recipiente que não os suporta, limitado que esta pelo sistema com um todo. Utilizar a capacidade contributiva como fonte da incidência tributária, outorgando poderes incompatíveis ao Poder Executivo, de definir o que seria tributável ou não, é ofender o basilar princípio da separação de poderes, usurpando das prerrogativas do Poder Legislativo, representante do povo, único competente para instituir tributos, utilizando se do seu poder imanente de inovação no sistema jurídico.

O vetor principal da incidência tributária, ao lado da legalidade estrita, é o princípio da tipicidade fechada, que seleciona os eventos do mundo fenomênico para a incidência dos tributos, de impossível limitação pelo princípio da capacidade contributiva, visto se apresentarem perante o sistema como regra e princípio correlatamente, operando, portanto, em plano diferentes, cedendo este espaço à aquele.

Impossível a pretensa utilização do método integrativo da analogia para aplicar norma tributária a fato jurídico extratípico de conseqüências econômicas equivalentes a fato jurídico típico, pois no referido método há verdadeira carga criativa, mesmo que relativa, incompatível com as funções inerentes ao Poder Executivo.

Intolerável o emprego da analogia por se encontrar ausente um de seus requisitos de validade, ou seja, a inexistência de lacunas em direito tributário no que se refere á incidência dos tributos, o que existe na realidade é uma "lacuna aparente", verdadeiro espaço livre do direito, albergado pelo princípio geral de liberdade.

\section{Referências}

BECKER, Alfredo Augusto. Teoria geral do direito tributário. 3. ed. São Paulo: Lejus, 1999.

CANOTILHO, José Joaquim Gomes. Direito constitucional e teoria da constituição. 5. ed. Coimbra: Livraria Almedina, 1999. 
CARDOSO, Lais Vieira. As doutrinas de prevalência da substância sobre a forma diante do parágrafo único do artigo 116 do código tributário nacional. In: CONGRESSO BRASILEIRO DE DIREITO TRIBUTÁRIO, 15., 2002, São Paulo. [Anais...]. São Paulo: [s.n.], 2002.

CARVALHO, Paulo de Barros. Curso de direito tributário. 8. ed. São Paulo: Saraiva, 1996. . Curso de direito tributário. 16. ed. São Paulo: Saraiva, 2004.

COLOMBO, Cristiano. O planejamento tributário e a norma antielisiva. In: CONGRESSO BRASILEIRO DE DIREITO TRIBUTÁRIO, 15., 2002, São Paulo. Anais... São Paulo: [s.n.], 2002.

PALHARES, Cinthia Rodrigues Menescal. A integração no Direito Tributário: considerações acerca do emprego da analogia. Jus Navigandi, Teresina, a. 6, n. 58, ago. 2002. Disponível em: <http://www1.jus.com.br/doutrina/texto.asp?id=3103>. Acesso em: 11 jun. 2004.

SAMPAIO DÓRIA, Antonio Roberto. Elisão e evasão fiscal. São Paulo: Lael, 1971.

TORRES, Heleno Taveira. Direito tributário e direito privado. São Paulo: Editora Revista dos Tribunais, 2003.

. Limites do planejamento tributário e a norma brasileira atisimulação (LC 104/01), Grandes questões atuais do direito tributário (coord. Valdir de Oliveira Rocha), São Paulo: Dialética, 2001.

XAVIER, Alberto. Tipicidade da tributação, simulação e norma antielisiva. 1. ed. São Paulo: Dialética, 2002. 
Revista de Direito Público, LondRina, v. 1, N. 2, P. 97-118, MAio/Ago. 2006. 